\title{
PENGARUH BERBAGAI PROPORSI PELARUT PADA EKSTRAKSI DAN STABILITAS ZAT WARNA ALAMI BUAH MANGSI (Phyllantus reticulatus)
}

\author{
The Influence of Various Proportions of Solvent on Extraction and Stability \\ of Natural Colorant From Mangsi Fruit (Phyllantus reticulatus)
}

\author{
Luqman Agung Wicaksono $^{\left.1^{*}\right)}$, Sri Winarti ${ }^{1)}$, Dita Amalusholikha ${ }^{2)}$ \\ 'Staff Pengajar Program Studi Teknologi Pangan, Fakultas Teknik, UPN “Veteran” Jawa Timur \\ 2Alumni Program Studi Teknologi Pangan, Fakultas Teknik,UPN “Veteran” Jawa Timur \\ Email: luqmanagungw@gmail.com
}

\begin{abstract}
ABSTRAK
Tanaman mangsi (Phyllanthus reticulatus) merupakan tanaman perdu yang tumbuh liar dengan buah yang berwarna ungu kehitaman yang diduga berasal dari antosianin. Antosianin yang bersifat polar dan larut dengan baik dalam pelarut-pelarut polar. Oleh sebab itu dalam penelitian ini digunakan pelarut etanol $96 \%$, asam asetat dan aquades dengan perbandingan yang berbeda. Penelitian ini bertujuan untuk mencari perbandingan pelarut (campuran etanol $96 \%$, asam asetat dan aquades) yang tepat untuk ekstraksi antosianin dan mengetahui stabilitas ekstrak warna antosianin buah mangsi yang dihasilkan. Penelitian ini terdiri dari dua tahap yaitu tahap I adalah ekstraksi zat warna alami dari buah mangsi (phyllanthus reticulatus) dengan berbagai proporsi pelarut (etanol $96 \%$, asam asetat dan aquades) (49:1:50 ;39:1:60 ; 29:1:70 ; 19:1:80 ; 9:1:90). Hasil penelitian tahap I menunjukkan bahwa perlakuan terbaik yang digunakan adalah perbandingan jenis pelarut etanol 96\% : asam asetat : aquades (9:1:90) menghasilkan nilai $\mathrm{pH}$ tertinggi yaitu 5,380 ; konsentrasi antosianin $0,455 \mathrm{mg} / \mathrm{l}$; rendemen ekstrak 74,40 \% ; tingkat kecerahan 23,73 ; tingkat kemerahan 9,07 ; tingkat kekuningan 10,23. Hasil analisa tahap II, menunjukkan bahwa ekstrak antosianin buah mangsi mengalami penurunan stabilitas yang dipengaruhi oleh $\mathrm{pH}$, suhu, dan waktu pemanasan. Peningkatan nilai pH menyebabkan nilai absorbansi ekstrak makin menurun, sedangkan semakin tinggi suhu dan lama waktu pemanasan menyebabkan stabilitas warna kurang optimum.
\end{abstract}

Kata kunci: Antosianin, Stabilitas warna, Ekstraksi, Buah mangsi

\begin{abstract}
Mangsi (Phyllanthus reticulatus) is a wild Evergreen shrub plant that grows with blackish purple fruit presumably comes from anthocyanins. Anthocyanins are polar and dissolves well in polar solvents. Therefore, in this study 96\% ethanol, acetic acid and aquades was used for extraction with different proportions. The aims of this research was to find comparisons of solvents (ethanol 96\%, acetic acid and aquades) for proper extraction of anthocyanin and find out the stability of anthocyanin produced from mangsi fruit extract. This study consists of two phases i.e. phase I was the extraction of natural colorants from mangsi with various proportions of solvent (ethanol 96\%, acetic acid and aquades) (49:1:50; 39:1:60; 29:1:70; 19:1:80; 9:1:90). The results of the research phase I indicates that the best treatment was the comparison of solvent type $96 \%$ ethanol: acetic acid: aquades (9:1:90) produces the best $p H$ values 5.380; the concentration of anthocyanin $0.455 \mathrm{mg} / \mathrm{l}$; yield of extract $74.40 \%$; brightness level 23.73; the redness level 9.07; and the yellowish level 10.23. The results of the analysis phase II indicate that extracts of anthocyanin from mangsi fruit decreased stability influenced by $\mathrm{pH}$, temperature, and time of heating. An increase in $\mathrm{pH}$ values cause the values of absorbance extract declining, whereas the higher the temperature and the longer time of heating causes less optimum color stability.
\end{abstract}

Keywords: Anthocyanin, Color Stability, Extraction, Mangsi Fruit 


\section{PENDAHULUAN}

Warna merupakan faktor kualitas yang penting pada makanan karena memegang peranan penting dalam penerimaan makanan. Menyadari pentingnya warna, maka produsen makanan seringkali menambahkan pewarna pada produk makanannya, baik berupa pewarna alami (pigmen) ataupun pewarna sintetik (Mortensen, 2006).

Perkembangan industri pengolahan pangan dan terbatasnya jumlah dan mutu zat pewarna alami, menyebabkan penggunaan zat warna sintetik meningkat. Sejak ditemukannya zat pewarna sintetik penggunaan pigmen sebagai zat pewarna alami semakin menurun. Zat pewarna sintetis memang terbukti lebih murah sehingga lebih menguntungkan dari segi ekonomis. Namun penggunaan pewarna sintetik sebagai pewarna makanan atau minuman dapat berdampak negatif yaitu bersifat toksik dan karsinogenik, karena kandungan logam berat yang berada dalam pewarna sintetik tidak dapat dihancurkan dalam sistem pencernaan manusia dan akan terakumulasi di dalam tubuh (Mastuti, dkk, 2013). Oleh karena itu pewarna sintetik dihindari dan mengkaji penggunaan pewarna alami.

Salah satu pigmen yang dapat diekstrak dari sumber bahan alami adalah antosianin yang tergolong dalam senyawa flavonoid. Pigmen ini berperan terhadap timbulnya warna merah hingga biru pada beberapa bunga, buah dan daun (Andersen dan Bernard, 2001).

Beberapa tanaman yang telah diteliti sebagai pewarna alami di antaranya adalah ekstrak buah arben (Tensiska dan Natalia, 2007), ekstraksi dan uji stabilitas zat warna alami dari buah lakum (Neliyanti dan Nora, 2014) dan ekstrak bunga rosella sebagai pewarna makanan dan minuman (Winarti dan Firdaus, 2010). Bahan pewarna alami yang dipilih berdasarkan ketersediaan di alam, dan kemudahan untuk memperolehnya, salah satu tanaman yang buahnya dapat digunakan sebagai sumber pewarna alami adalah tanaman mangsimangsian (Phyllanthus reticulatus).

Phyllanthus reticulatus adalah keluarga Euphorbiaceae yang tumbuh sebagai semaksemak. Selain di Indonesia, tanaman ini banyak tumbuh di seluruh India, dan Afrika. Di Indonesia dikenal dengan nama buah mangsi atau buah tinta. Buah ini dapat menghasilkan zat warna alami berwarna hitam kebiruan. Buah Phyllanthus reticulatus berbentuk seperti berry bulat gepeng, diameter hingga $7 \mathrm{~mm}$, biasanya hitam kebiruan (Patil dan Jadhav, 2012). Di daerah Arika, buah mangsi banyak dimanfaatkan sebagai obat peradangan usus dan bersifat astringen (suatu efek mengecilkan pori-pori permukaan usus sehingga mengurangi absorbsi pada permukaan usus (Sharma dan Kumar, 2013). Namun buah mangsi di Indonesia belum banyak dimanfaatkan dan dipublikasikan, oleh karena itu perlu dilakukan penelitian tentang ekstraksi dan stabilitas zat warna alami pada buah mangsi.

Isolasi pigmen dapat dilakukan dengan cara mengekstrak bahan dengan menggunakan pelarut yang sesuai dengan kepolarannya dengan zat yang akan diekstrak. Ekstraksi senyawa golongan flavonoid dianjurkan dilakukan pada suasana asam karena asam berfungsi mendenaturasi membran sel tanaman, kemudian melarutkan pigmen antosianin sehingga dapat keluar dari sel, serta mencegah oksidasi flavonoid (Robinson, 1995).

Zat warna alami yang terdapat di dalam buah mangsi diduga adalah kelompok antosianin. Antosianin adalah kelompok pigmen yang menyebabkan warna oranye, merah muda, merah, ungu hingga biru. Penelitian yang dilakukan oleh (Hariyani., dkk, 2013) menyatakan bahwa hasil pemeriksaan spektrofotometri Phyllanthus reticulatus (buah mangsi) diketahui memiliki jenis senyawa kimia yaitu flavonoid dengan jumlah kandungan total flavonoid sebesar 3,75\%. Antosianin pada umumnya larut dalam air. Warna pigmen antosianin merah, biru, dan violet biasanya dijumpai pada bunga, buah-buahan dan sayur-sayuran. Dalam tanaman terdapat dalam bentuk glikosida yaitu membentuk ester dengan monosakarida (glukosa, galaktosa, ramnosa dan pentosa), sehingga buah mangsi memiliki potensi untuk dijadikan sebagai pewarna alami.

Hanum (2000), meneliti tentang ekstraksi dan stabilitas warna alami dari katul beras ketan hitam. Hasil yang diperoleh bahwa homogenat yang diekstrak dengan penambahan campuran metanol - asam (metanol : asam asetat : air = 10:1:10) hingga volume $120 \mathrm{ml}$ selama 12 jam dapat dihasilkan konsentrasi antosianin dan rendemen yang tertinggi serta dengan kondisi konsentrat 5,5 menunjukkan penurunan kadar pigmen yang lebih besar atau paling tidak stabil dibandingkan dengan kondisi $\mathrm{pH}$ dibawah yaitu pH 3,5 dan 4,5.

Neliyanti dan Nora (2014) melakukan 
penelitian tentang ekstraksi dan uji stabilitas zat warna alami dari buah lakum. Penggunaan pelarut air dan variasi konsentrasi etanol $96 \%$ pada proses ekstraksi didasarkan pada warna pigmen yang terkandung dalam buah lakum. Berdasarkan hasil penelitian diperoleh ekstraksi optimum untuk pelarut air pada suhu $70^{\circ} \mathrm{C}$ dan pelarut etanol dengan konsentrasi 60 $\%$. Untuk hasil uji signifikansi menunjukkan stabilitas warna buah lakum dipengaruhi oleh suhu penyimpanan, cahaya, $\mathrm{pH}$ dan oksidator dengan terjadinya penurunan nilai absorbansi setelah perlakuan, sehingga menunjukkan bahwa antosianin buah lakum lebih stabil pada penyimpanan suhu rendah, tanpa cahaya, tanpa penambahan oksidator dan stabil pada $\mathrm{pH}$ asam ( $\mathrm{pH} 1$ dan 2).

Winarti dkk (2008) meneliti tentang ekstraksi dan stabilitas warna ubi jalar ungu (Ipomoea batatas L). Komposisi pelarut yang digunakan pada ekstraksi ini adalah etanol $96 \%$ : asam asetat : air (25:1:5) menunjukan intensitas warna antosianin terbaik dengan menghasilkan ekstrak warna dari ubi jalar ungu (konsentrasi antosianin) tertinggi yaitu $1,3170 \mathrm{mg} / 100 \mathrm{~g}$.

Gao dan Mazza (1996) melakukan penelitian tentang ekstraksi pigmen antosianin pada biji bunga matahari yang berwarna ungu. Komposisi pelarut yang digunakan untuk ekstraksi adalah etanol : asam asetat : air $=$ 50:1:49. Hasil yang diperoleh dengan pelarut asam alkohol sangat efektif dalam mengekstraksi antosianin dari bahan tanaman.

Pigmen antosianin termasuk senyawa polar dan dapat diekstraksi dengan baik dalam pelarutpelarut yang bersifat polar pula. Beberapa penelitian ekstrak antosianin menggunakan pelarut yang bersifat polar di antaranya etanol, air, dan asam asetat karena sifatnya yang polar dan mudah larut dengan air. Oleh sebab itu pada penelitian ini dilakukan ekstraksi antosianin dengan jenis pelarut campuran etanol 96\%, asam asetat dan aquades dengan perbandingan tertentu. Selanjutnya hasil zat warna antosianin yang diperoleh dari perlakuan terbaik diuji stabilitasnya terhadap pengaruh $\mathrm{pH}$, suhu pemanasan, dan lama pemanasan.

\section{METODE PENELITIAN}

\section{Bahan}

Bahan yang digunakan adalah buah mangsi (Phyllanthus reticulatus) yang diperoleh dari daerah Rungkut, Kenjeran, dan Kedung baruk kota Surabaya, asam asetat, etanol $96 \%$, sianidin 3-glikosida, larutan buffer asam sitrat - dibasic sodium phosphatepH 3 , dan aquades.

Alat

Peralatan yang digunakan adalah Spektrofotometri UV-Vis 10S, Spektrofotometri Spectronic 21D), rotary evaporator, blender, kertas saring, water bath, labu ukur, corong, erlenmeyer, gelas piala, gelas ukur, $\mathrm{pH}$ meter dan timbangan analitik.

\section{Metode}

Penelitian ini menggunakan 2 tahap dalam analisa. Tahap I : ekstraksi zat warna alami dari buah mangsi dengan proporsi pelarut yang berbeda (etanol $96 \%$, asam asetat dan aquades) masing-masing dengan proporsi $\mathrm{Al}_{1}(49: 1: 50)$; A2(39: $\left.1: 60\right) ; \mathrm{A}_{3}(29: 1: 70) ; \mathrm{A}_{4}(19$ : 1 :80); A5(9: 1 :90). Tahap II : stabilitas ekstrak buah mangsi terbaik pada berbagai suhu, waktu pemanasan dan $\mathrm{pH}$. Rancangan percobaan yang digunakan adalah rancangan acak lengkap (RAL) faktor tunggal dan 3 kali ulangan. Parameter yang diamati meliputi $\mathrm{pH}$ pelarut, rendemen ekstrak, $\mathrm{pH}$ ekstrak, konsentrasi ekstrak, intensitas warna ekstrak, dan stabilitas terhadap $\mathrm{pH}$, suhu serta lama pemanasan. Data yang diperoleh dianalisis menggunakan analisis ragam (ANOVA), untuk mengetahui adanya perbedaan diantara perlakuan digunakan uji DMRT dengan taraf $5 \%$.

\section{HASIL DAN PEMBAHASAN}

\section{Hasil Analisa pH Pelarut}

Hasil analisa nilai pH pelarut yang akan digunakan untuk proses ekstraksi buah mangsi dapat dilihat pada Tabel 1. 
Tabel 1. Nilai rata-rata $\mathrm{pH}$ pada perlakuan perbandingan jenis pelarut.

\begin{tabular}{lclll}
\hline & $\begin{array}{c}\text { Perbandingan Pelarut } \\
(\text { Etanol } \mathbf{9 6 \%}: \text { As. Asetat : Aquades) }\end{array}$ & pH & DMRT 5\% & Notasi \\
\hline A1 & $49: 1: 50$ & 3,71 & 0,0277 & e \\
A2 & $39: 1: 60$ & 3,57 & 0,0273 & $\mathrm{~d}$ \\
A3 & $29: 1: 70$ & 3,52 & 0,0266 & $\mathrm{c}$ \\
A4 & $19: 1: 80$ & 3,44 & 0,0255 & $\mathrm{~b}$ \\
A5 & $9: 1: 90$ & 3,35 & - & $\mathrm{a}$ \\
\hline
\end{tabular}

\section{Analisa Sifat Fisiko Kimia Ekstrak Buah \\ Mangsi}

\section{Rendemen Ekstrak Buah Mangsi}

Berdasarkan analisis ragam, diketahui bahwa perbandingan jenis pelarut berpengaruh nyata terhadap rendemen ekstrak buah mangsi ( $\mathrm{p} \leq 0,05)$. Grafik pengaruh perbandingan jenis pelarut terhadap rendemen antosianin dapat dilihat pada Gambar 1.

Gambar 1 menunjukkan bahwa semakin rendah jumlah etanol dan semakin tinggi jumlah aquades maka rendemen ekstrak buah mangsi semakin tinggi. Hal ini disebabkan oleh tingkat kepolaran pelarut yang digunakan untuk proses ekstraksi antosianin buah mangsi.
Akibatnya akan semakin banyak komponen yang terekstrak. Hal ini didukung oleh Tensiska dan Natalia (2007) yang menyatakan bahwa keadaan pelarut yang semakin asam menyebabkan semakin banyak dinding sel vakuola yang pecah sehingga pigmen antosianin semakin banyak terekstrak. Hal ini juga didukung oleh Calinescu $d k k$. (2001) yang menyatakan bahwa penggunaan pelarut yang sesuai dengan kepolaran bahan serta volume pelarut yang lebih banyak menyebabkan pembengkakan sel dan tekanan mendorong dinding sel dari dalam, meregangkan, dan memecah sel tersebut, sehingga semakin banyaknya volume pelarut menyebabkan rendemen semakin tinggi.

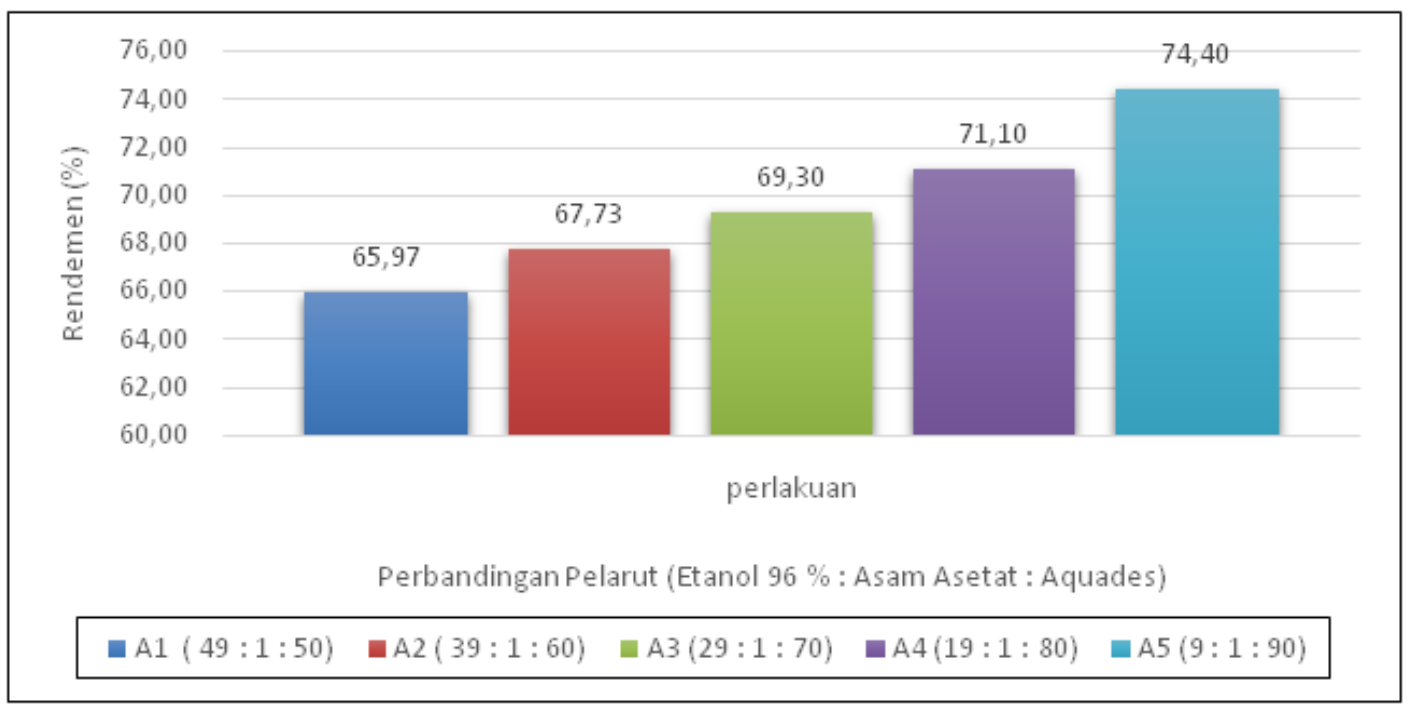

Gambar 1. Pengaruh perbandingan jenis pelarut terhadap rendemen ekstrak buah mangsi

\section{pH Ekstrak Buah Mangsi}

Berdasarkan hasil analisa ragam, diketahui perbandingan jenis pelarut berpengaruh nyata terhadap pH ekstrak buah mangsi ( $\mathrm{p} \leq \mathrm{0}, 05)$. Grafik pengaruh perbandingan jenis pelarut terhadap $\mathrm{pH}$ pelarut dapat dilihat pada Gambar 2. 


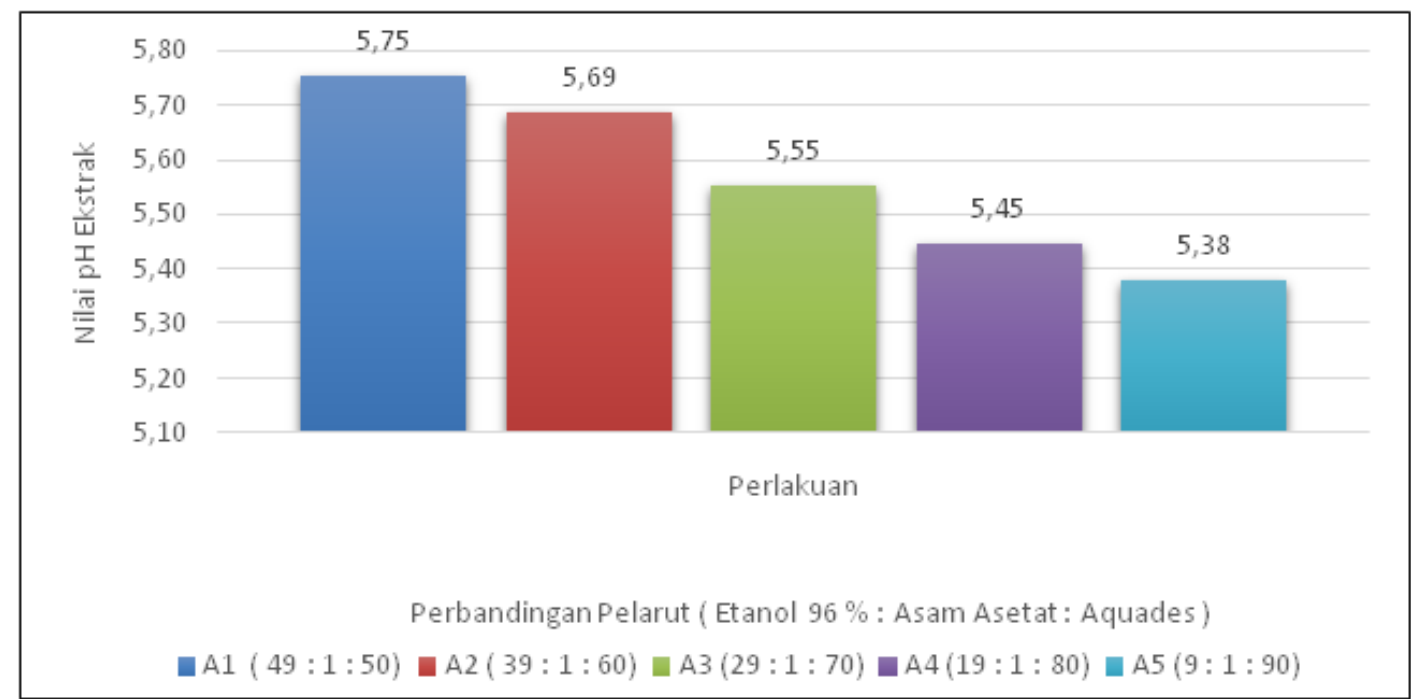

Gambar 2. Pengaruh perbandingan pelarut terhadap pH ekstrak

Gambar 2 menunjukkan bahwa semakin turun jumlah etanol dan semakin tinggi jumlah aquades, maka nilai pH ekstrak buah mangsi semakin menurun. Hal ini disebabkan oleh penggunaan asam yang ditambahkan ke dalam pelarut etanol yang bersifat basa lemah dan aquades yang bersifat netral, sehingga dengan adanya asam dan basa lemah yang ditambahkan maka $\mathrm{pH}$ ekstrak buah mangsi semakin rendah. Hal ini sesuai dengan pernyataan Fessenden dan Fessenden (1982) yang menyatakan bahwa etanol merupakan basa lemah. Hal ini juga didukung oleh Azmi dan Yunianta (2015) yang menyatakan bahwa penggunaan asam yang ditambahkan ke dalam pelarut berfungsi agar pelarut dalam kondisi asam sehingga akan mendenaturasi membran sel dari partikelpartikel buah murbei kemudian melarutkan pigmen antosianin keluar dari sel.

\section{Konsentrasi Antosianin Ekstrak Buah \\ Mangsi}

Berdasarkan analisis ragam, diketahui bahwa perbandingan jenis pelarut berpengaruh nyata terhadap konsentrasi antosianin $(\mathrm{p} \leq 0,05)$. Grafik pengaruh perbandingan jenis pelarut terhadap kada antosianin ekstrak buah mangsi dapat dilihat pada Gambar 3.

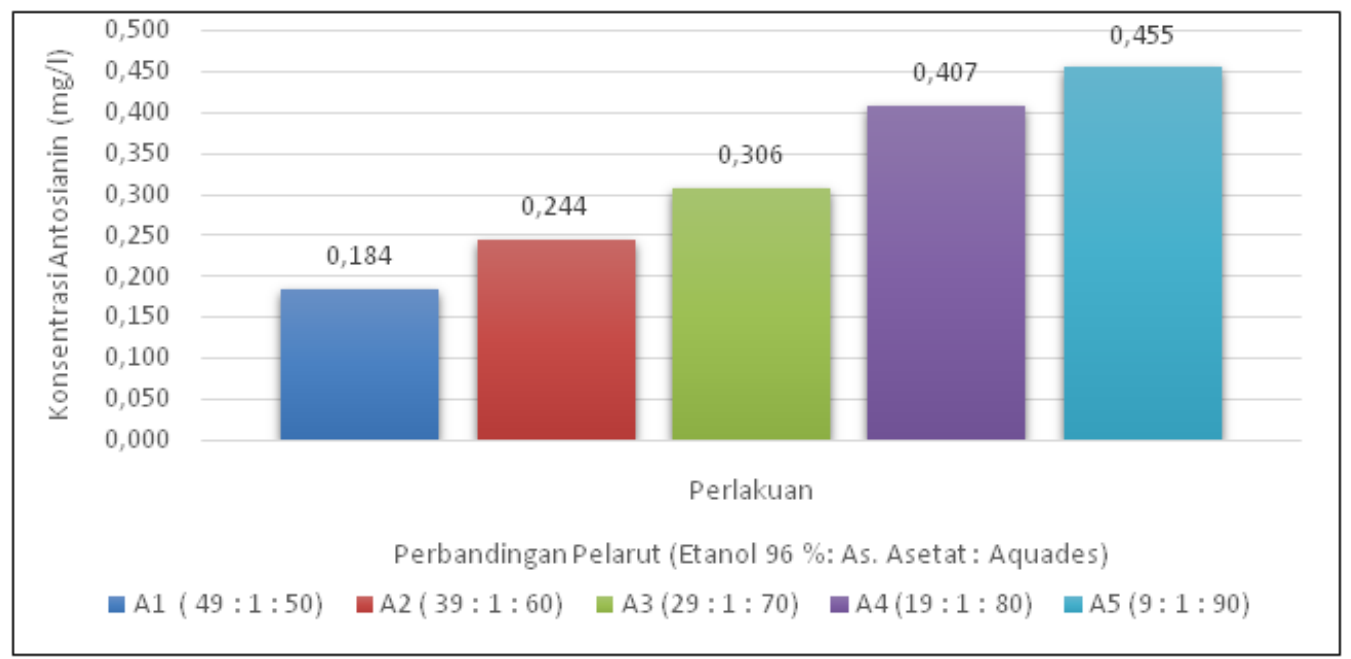

Gambar 3. Pengaruh perbandingan pelarut terhadap konsentrasi antosianin ekstrak buah mangsi 
Gambar 3 menunjukkan bahwa semakin rendah jumlah etanol dan semakin tinggi jumlah aquades maka konsentrasi antosianin semakin meningkat. Hal ini disebabkan karena kepolaran dari kedua pelarut terhadap buah mangsi dimana semakin rendah jumlah etanol dan semakin tinggi jumlah aquades maka konsentrasi antosianin yg didapat semakin tinggi. Hal ini juga berpengaruh pada hasil rendemen dimana hasil rendemen tertinggi juga dapat meningkatkan konsentrasi antosianin. Hal ini didukung oleh Sari dkk. (2005), menyatakan bahwa penggunaan pelarut aquades yang lebih tinggi dibanding dengan pelarut etanol yang dikombinasikan maka dapat meningkatkan polaritas. Sifat kepolaran pelarut berpengaruh pada konsentrasi anotsianin yang terekstrak. Semakin polar pelarut maka konsentrasi antosianin semakin tinggi.

\section{Intensitas Warna Ekstrak Buah Mangsi}

Berdasarkan analisis ragam diketahui bahwa perbandingan jenis pelarut tidak berpengaruh nyata terhadap intensitas warna antosianin $(\mathrm{p} \geq 0,05)$. Nilai rata-rata intensitas warna (Nilai $\mathrm{L}^{*}, \mathrm{a}^{+}, \mathrm{b}^{+}$) yang dihasilkan dapat dilihat pada Tabel 2.

Tabel 2. Nilai rata-rata intensitas warna $\left(\mathrm{L}^{*}, \mathrm{a}^{*}, \mathrm{~b}^{*}\right)$ pada perlakuan perbandingan jenis pelarut

\begin{tabular}{|c|c|c|c|c|c|c|c|}
\hline \multirow{3}{*}{\multicolumn{2}{|c|}{$\begin{array}{c}\text { Perb. Pelarut } \\
\text { (etanol } 96 \% \text { : asam } \\
\text { asetat : aquades) } \\
\text { Nilai } \\
\text { L }^{*}\end{array}$}} & \multicolumn{2}{|c|}{$\begin{array}{c}\text { Tingkat } \\
\text { Kecerahan }\left(L^{*}\right)\end{array}$} & \multicolumn{2}{|c|}{$\begin{array}{c}\text { Tingkat } \\
\text { Kemerahan }\left(a^{*}\right)\end{array}$} & \multicolumn{2}{|c|}{$\begin{array}{c}\text { Tingkat } \\
\text { Kekuningan }\left(\mathbf{b}^{*}\right)\end{array}$} \\
\hline & & \multirow{2}{*}{$\begin{array}{c}\text { DMRT } \\
5 \%\end{array}$} & Nilai & \multirow{2}{*}{$\begin{array}{c}\text { DMRT } \\
5 \%\end{array}$} & \multirow{2}{*}{$\begin{array}{c}\text { Nilai } \\
\mathbf{b}^{*}\end{array}$} & \multirow{2}{*}{$\begin{array}{c}\text { DMRT } \\
5 \%\end{array}$} & \\
\hline & & & $a^{*}$ & & & & \\
\hline$A_{1}$ & $49: 1: 50$ & $19,87^{\mathrm{a}}$ & - & $6,46^{a}$ & - & $7,1^{a}$ & - \\
\hline $\mathrm{A} 2$ & $39: 1: 60$ & $20,76^{a}$ & 2,27 & $7,13^{a}$ & 1,60 & $8,23^{a}$ & 1,85 \\
\hline$A_{3}$ & $29: 1: 70$ & $21,87^{\mathrm{a}}$ & 2,39 & $8,0^{a}$ & 1,69 & $9,0^{a}$ & 1,95 \\
\hline $\mathrm{A}_{4}$ & $19: 1: 80$ & $22,7^{\mathrm{a}}$ & 2,47 & $8,77^{\mathrm{a}}$ & 1,75 & $9,63^{a}$ & 2,02 \\
\hline $\mathrm{A}_{5}$ & $9: 1: 90$ & $23,73^{\mathrm{a}}$ & 2,53 & $9,07^{\mathrm{a}}$ & 1,7 & $10,23^{a}$ & 2,07 \\
\hline
\end{tabular}

Tabel 2. menunjukkan bahwa nilai kemerahan rata-rata ekstrak buah mangsi berkisar antara 6,46 - 9,07. Nilai kemerahan tertinggi diperoleh perlakuan dengan perbandingan pelarut etanol $96 \%$ : asam asetat : aquades (9:1:90) yaitu 9,07, sedangkan nilai kemerahan terendah diperoleh perlakuan dengan perbandingan pelarut etanol $96 \%$ : asam asetat : aquades (49:1:50) yaitu 6,46.

\section{UJI STABILITAS}

\section{Stabilitas Warna Ekstrak Buah Mangsi terhadap Pengaruh pH}

Hasil rata-rata nilai absorbansi untuk setiap perlakuan $\mathrm{pH}$ dapat dilihat pada Gambar 4.

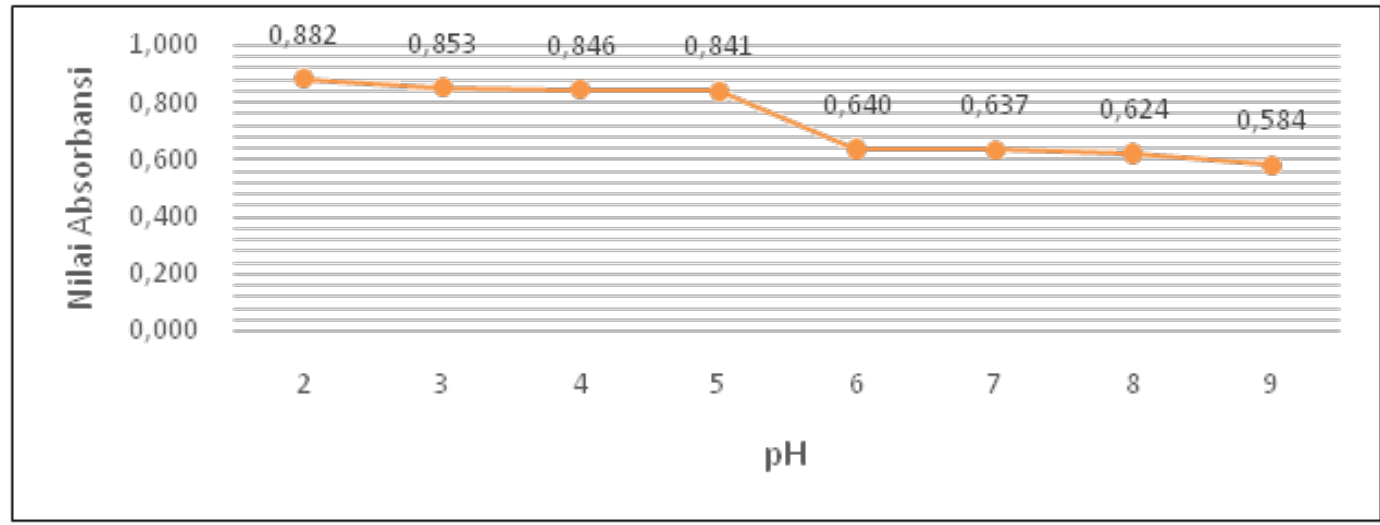

Gambar 4. Spektrum absorbansi warna ekstrak buah mangsi terhadap pengaruh $\mathrm{pH}$ 
Gambar 4 menunjukkan bahwa semakin tinggi nilai $\mathrm{pH}$ maka nilai absorbansi akan semakin rendah. Hal ini terlihat bahwa intensitas warna yang ditunjukkan oleh nilai absorbansi, nilainya semakin menurun dengan meningkatnya nilai $\mathrm{pH}$. Pada $\mathrm{pH} 2$ sampai dengan 4 nilai absorbansi masih stabil dan terjadi penurunan sangat tajam pada $\mathrm{pH} 5$ menuju $\mathrm{pH}$ 6. Hal ini sesuai dengan penelitian Hanum (2000), bahwa kondisi pH 5,5 menunjukkan penurunan kadar pigmen yang lebih besar atau paling tidak stabil dibandingkan dengan kondisi $\mathrm{pH}$ di bawahnya yaitu $\mathrm{pH}$ 3,5 dan 4,5.

\section{Stabilitas Warna Ekstrak Buah Mangsi terhadap Pengaruh Suhu Pemanasan}

Hasil rata-rata nilai absorbansi untuk setiap perlakuan dapat dilihat pada Gambar 5.

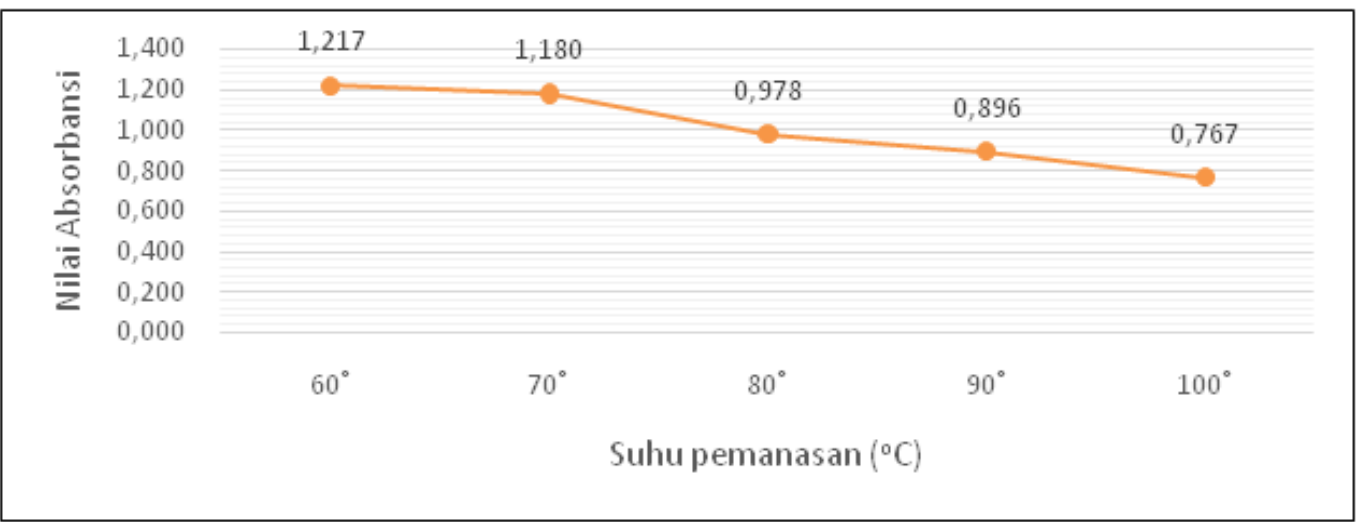

Gambar 5. Spektrum absorbansi warna ekstrak buah mangsi terhadap pengaruh Suhu Pemanasan

Gambar 5 menunjukkan bahwa semakin meningkatnya suhu pemanasan maka nilai absorbansi semakin menurun. Hal ini disebabkan degradasi antosianin karena suhu tinggi, ditunjukkan pada pemanasan suhu $60^{\circ} \mathrm{C}$ hingga $100^{\circ} \mathrm{C}$ mengalami penurunan nilai absorbansi. Ekstrak buah mangsi yang diperoleh bersifat tidak stabil terhadap pemanasan. Hal ini sesuai dengan penelitian yang dilakukan oleh Cacace dan Mazza (2003), bahwa ekstraksi antosianin dari blackcarrot dengan penggunaan suhu tinggi mempengaruhi degradasi antosianin dari bentuk aglikon menjadi kalkon (tidak berwarna) dan akhirnya membentuk alfa diketon yang berwarna coklat.

\section{Stabilitas Warna Ekstrak Buah Mangsi}

Terhadap Pengaruh Lama Pemanasan

Hasil rata-rata nilai absorbansi untuk setiap perlakuan dapat dilihat pada gambar 6 .

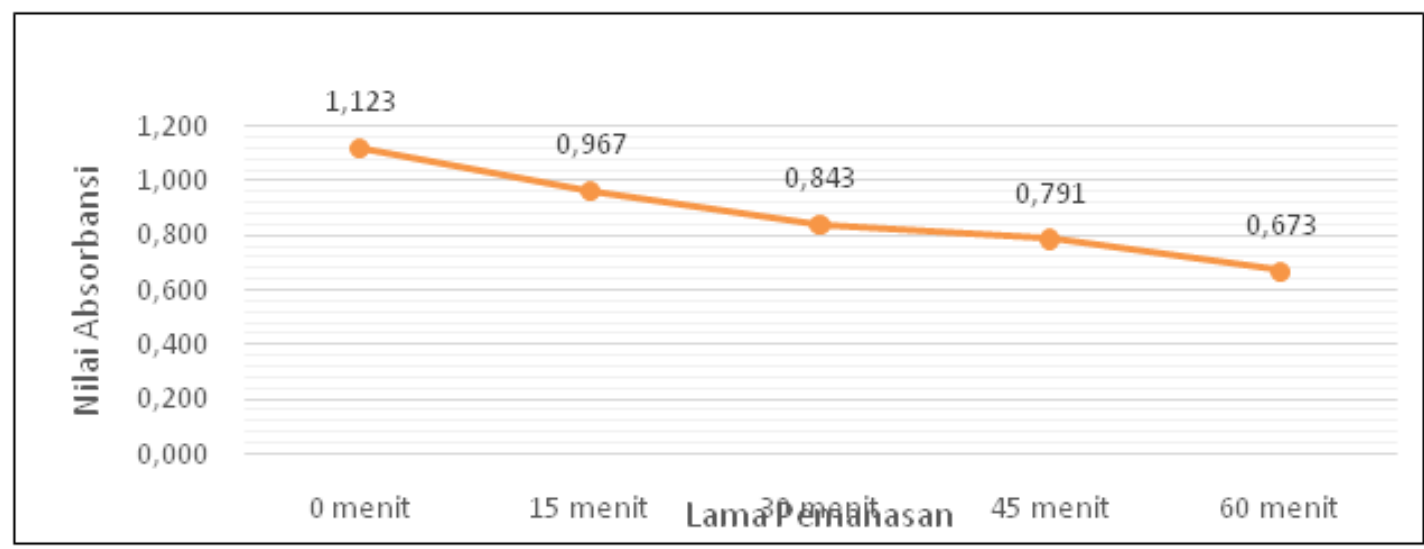

Gambar 6. Spektrum absorbansi warna ekstrak buah mangsi terhadap pengaruh lama pemanasan 
Gambar 6 menunjukkan bahwa semakin lama waktu pemanasan maka nilai absorbansi semakin menurun. Hal ini disebabkan karena stabilitas warna antosianin buah mangsi tidak stabil pada proses pemanasan sehingga semakin lamanya waktu pemanasan maka akan mengakibatkan pigmen antosianin mengalami dekomposisi dan nilai absorbansinya menurun. Hal ini ditunjukkan pada waktu pemanasan o menit sampai dengan 6o menit mengalami penurunan nilai absorbansi cukup tinggi. Menurut Sutrisno (1987) dalam Wijaya dkk. (2001) menyatakan bahwa suhu dan lama pemanasan menyebabkan terjadinya dekomposisi dan perubahan struktur pigmen sehingga terjadi pemucatan warna. Hasil penelitian ekstrakasi dari katul beras ketan hitam oleh Hanum (2000), juga menunjukkan bahwa pemanasan pada suhu $100^{\circ} \mathrm{C}$ selama 4 jam secara terus-menerus dapat menurunkan stabilitas warna antosianin.

\section{KESIMPULAN}

Dari hasil penelitian yang telah dilakukan dapat diperoleh kesimpulan bahwa perlakuan terbaik diperoleh pada perbandingan jenis pelarut etanol $96 \%$ : asam asetat : aquades (9:1:90) dengan nilai $\mathrm{pH}$ pelarut 3,35 dan $\mathrm{pH}$ ekstrak 5,38 menghasilkan rendemen ekstrak sebesar $74,40 \%$ dan konsentrasi antosianin sebesar 0,455 mg/l dengan tingkat kemerahan (a*) 9,07.

Hasil uji stabilitas menunjukkan bahwa ekstrak antosianin buah mangsi mengalami penurunan stabilitas yang dipengaruhi oleh $\mathrm{pH}$, suhu, dan waktu pemanasan. Peningkatan nilai pH menyebabkan nilai absorbansi ekstrak makin menurun, sedangkan semakin tinggi suhu dan lama waktu pemanasan menyebabkan stabilitas warna kurang optimum.

\section{DAFTAR PUSTAKA}

Andersen, O.M., dan Bernard, K., 2001. Chemistry Analysis and Application of Anthocyanin Pigments from Flowers, Fruits and Vegetables. New York: Taylor and Francis Group LLC.

Azmi, A.N., dan Yunianta, 2015. Ekstraksi Antosianin dari Buah Murbei (Morus alba. L) Metode Microwave Assisted Extraction (Kajian Waktu Ekstraksi dan Rasio Bahan:Pelarut)[IN PRESS JULI 2014]. Jurnal Pangan dan
Agroindustri, 3(3).

Cacace, J. E., dan Mazza, G., 2003. Extraction of anthocyanins and other phenolics from black currants with sulfured water. Journal of agricultural and food chemistry, 5o(21):5939-5946.

Calinescu, I., Ciuculescu, C., Popescu, M., Bajenaru, S., dan Epure, G, 2001. Microwave Assisted Extraction of Active Principles from Vegetal Material. Romanian International Conference on Chemistry and Chemical Engineering, 12: 1-6

Fessenden, R.J. and Fessenden, J.S., 1982, Kimia Organik, diterjemahkan oleh. Pudjaatmakan, A. H., Edisi Ketiga, Jilid 1, 237-239, Jakarta: Penerbit Erlangga

Gao, L., dan Mazza, G., 1996. Extraction of anthocyanin pigments from purple sunflower hulls. Journal of Food Science, 61(3):600-603.

Hanum, T, 2000. Ekstraksi dan Stabilitas Zat Pewarna Alam dari Katul Beras Ketan Hitam (Oryza sativaglutinosa). Buletin TeknologidanIndustriPanganı1(1):17-23 Hariyani, T, D., Suranto dan Purwanto, E., 2013. Studi Variasi Anatomi dan Kandungan Flavonoid Lima Spesies Anggota Genus Phyllanthus. Tesis. Program Studi Biosains Universitas Negeri Sebelas Maret. Solo

Mastuti, E., Wenaputri, M.G.N., dan Hariyandi, P., 2013. Ekstraksi zat warna alami kelopak bunga rosella dengan pelarut etanol. EQUILIBRIUM Journal of Chemical Engineering, 12(2): 49-53.

Mortensen, A., 2006. Carotenoids and other pigment as natural colorant. Pure Appl. Chem. 78(8): 1477-1491

Neliyanti dan Nora,I., 2014. Ekstraksi dan Uji Stabilitas Zat Warna Alami dari Buah Lakum (Cayratia trifolia (L.) Domin)JurnalKimiaKhatulistiwa3(2)

Patil, M.V., dan Jadhav, R, 2012. Use of Phyllanthus Reticulatus fruit extract as a natural indicator in acid base titration. International Journal of Pharmacy and Pharmaceutical Sciences, 4:490-491.

Robinson, T., 1995. Kandungan Organik Tumbuhan Tinggi. Edisi ke-6. Penerjemah : Kosasih Padmawinata. Penerbit ITB. Bandung.

Sari, P., Agustina, F., Komar M., Unus, Fauzi, M., dan Lindriati, T., 2005. Ekstraksi 
dan Stabilitas Antosianin dari Kulit Buah Duwet (Syzgyium cumini). Jurnal Teknologi dan Industri Pangan,16(2)

Sharma, S., dan Kumar, S., 2013. Phyllanthus reticulatus Poir.-An Important Medicinal Plant: A Review of Its Phytochemistry, Traditional Uses and Pharmacological Properties. International Journal of Pharmaceutical Sciences E Research,4:2528-2534.

Sutrisno, A. D., 1987. Pembuatan dan Peningkatan Kualitas Zat Warna Alami yang Dihasilkan Oleh Monascus purpeus sp. Di dalam Risalah Seminar Bahan Tambahan Kimiawi. PAU Pangan dan Gizi. Yogyakarta.

Tensiska, E.S., dan Natalia, 2007. Ekstraksi Pewarna Alami dari Buah Arben (Rubus idaeus (Linn.) dan Aplikasinya Pada
Sistem Pangan. Jurnal Teknologi dan Industri Pangan,18(1):25-31.

Wijaya, L.S., S.B. Widjanarko., dan T. Susanto, 2001. Ekstraksi dan Karakteristik Pigmen dari Kulit Buah Rambutan (Nephelium lappaceum) var. Binjai. Jurnal Teknologi Pangan dan Gizi, 2(1):1-16

Winarti, S., dan Firdaus, A. 2010. Stabilitas Warna Merah Ekstrak Bunga Rosela untuk Pewarna Makanan dan Minuman. Jurnal Teknologi Pertanian 11: 87-93

Winarti, S., Sarofa, U., dan Anggrahini, D. 2008. Ekstraksi dan Stabilitas Warna Ubi Jalar Ungu (Ipomoea batatas L.) Sebagai Pewarna Alami. Skripsi. Jurusan Teknologi Pangan Fakultas Teknologi Industri UPN “Veteran” Jawa Timur. Surabaya. 